\title{
PW03-033 - SLC29A3 mutation: a new autoinflammatory condition
}

\author{
I Melki ${ }^{1,2^{*}}$, K Lambot $^{3}$, L Jonard ${ }^{4}$, V Couloigner ${ }^{5,6}$, P Quartier ${ }^{1,5}$, B Neven ${ }^{1,5,7}$, B Bader-Meunier ${ }^{1,5,7}$ \\ From 7th Congress of International Society of Systemic Auto-Inflammatory Diseases (ISSAID) \\ Lausanne, Switerland. 22-26 May 2013
}

\section{Introduction}

Germline mutations in $S L C 29 A 3$ result in a range of clinically related, recessive syndromes: $\mathrm{H}$ syndrome, pigmented hypertrichosis with insulin-dependent diabetes mellitus (PHID) syndrome, Faisalabad histiocytosis (FHC), and sinus histiocytosis with massive lymphadenopathy (SHML). Main symptoms of these diseases are hyperpigmentation with hypertrichosis, sensorineural deafness, diabetes, short stature, uveitis and "Rosai-Dorfman-like" histiocytosis.

\section{Case report}

We report the case of an eleven-month-old boy with early-onset recurrent episodes of unprovoked fever lasting 7 to 10 days associated with pericardial effusion, abdominal pain, diarrhea, and inflammation. Physical examination revealed hyperpigmentation with hypertrichosis, dysmorphic features and a spleen and liver enlargement. Failure to thrive, sensorineural deafness, psychomotor development delay, and a "Rosai-Dorfman like" cheek lesion further developed. Febrile attacks were not responsive to interleukin-1 and Tumor-Necrosis-Factor blocking agents. All known causes of genetic autoinflammatory syndromes were excluded by sequencing (MEFV, NALP3, mevalonate kinase, NALP12, TNFRSF1). Sequencing of SLC29A3 gene revealed homozygous missense mutation c.1088G>A (p.Arg363Gln).

\section{Discussion}

This case is the first description of a patient with an autoinflammatory disorder due to a mutation in $S L C 29 A 3$ gene. Genetic defect of $S L C 29 A 3$ should be considered in patients with recurrent febrile attacks associated with any symptoms reminiscent of SLC29A3 broad spectrum of

${ }^{1}$ Unité d'Immunologie Hématologie et Rhumatologie Pédiatrique, NeckerEnfants Malades Hospital, Paris, France

Full list of author information is available at the end of the article manifestations, especially hyperpigmentation with hypertrichosis.

\section{Disclosure of interest}

None declared.

\section{Authors' details}

'Unité d'Immunologie Hématologie et Rhumatologie Pédiatrique, NeckerEnfants Malades Hospital, Paris, France. ²Service de Pédiatrie Générale, Robert Debré Hospital, France. ${ }^{3}$ Department of pediatric radiology, Necker-Enfants Malades Hospital, France. ${ }^{4}$ Department of genetics, Trouseau Hospital, France. ${ }^{5}$ Institut IMAGINE, Paris Descartes University, Sorbonne Paris Cité, France. ${ }^{6}$ Department of Microbiology, Necker Enfants Malades Hospital, France. ${ }^{7}$ U768, INSERM, Paris, France.

Published: 8 November 2013

doi:10.1186/1546-0096-11-S1-A259

Cite this article as: Melki et al:: PW03-033 - SLC29A3 mutation: a new autoinflammatory condition. Pediatric Rheumatology 2013 11(Suppl 1):A259.
Submit your next manuscript to BioMed Central and take full advantage of:

- Convenient online submission

- Thorough peer review

- No space constraints or color figure charges

- Immediate publication on acceptance

- Inclusion in PubMed, CAS, Scopus and Google Scholar

- Research which is freely available for redistribution

\section{() Biomed Central}

() Biomed Central

(c) 2013 Melki et al; licensee BioMed Central Ltd. This is an Open Access article distributed under the terms of the Creative Commons Attribution License (http://creativecommons.org/licenses/by/2.0), which permits unrestricted use, distribution, and reproduction in any medium, provided the original work is properly cited. 